bring Maxauaws into the body politic of the Republic of the Philippines. 1950. viii, I64 1.

3. Quemada, David V. Major influences on seven leading Philippine poets in English (José Garcia Villa, R. Zulueta da Costa, Trindad Tarrosa Subido, Angela Manalang Gloria, Bienvenido M. Santos, Homero Ch. Veloso, and Edith L. Tiempo) since 1930. 1953. viii, 3201.

Reel 2.

I. Binacro, Rosario V. A critical evaluation of the plays of Buenaventura Rodriguez, leading Cebuano dramatist. 1953. x60 1.

2. Divina, Abundis Tangeres. A critical study of the short stories of Manuel E. Arguilla. 1963. viii, 1301.

Reel 3 .

I. Dignadice, $\mathrm{Fe}$ Java. A critical study of folklore in the western Bisayas (Antique, Capiz, Iloilo, and Negros Occidental). I955. vii, 438 l.

2. Añonuevo-Yaptenco, Carminia. A critical study of Nick Joaquin's Prose and Poems. I959. v, 342 l.

\section{Kazi U-gyen and Lord Curzon's Letter of 1901: A Footnote}

The recent availability of new archival records shed a fresh gleam of light on the letter of Lord Curzon to the r $3^{\text {th }}$ Dalai Lama written sometime in rgor and carried to Lhasa by Kazi U-gyen, the then Bhutanese vakil stationed in Darjeeling. That the matter was rated sufficiently important as to be brought up in conversation at the time Lord Minto received the Lama in audience at Government House in Calcutta is evident from the Foreign/Department "notes" that were kept on the occasion.

Questioned by His Excellency as to what were the real facts of his treatment of Lord Curzon's letter ... he (Dalai Lama) said that U-gyen Kazi had come into his presence, but that he (Dalai Lama) had told him (U-gyen Kazi) that he could not receive the letter except through the Amban, and he advised U-gyen Kazi in his own interests to go away quietly as the Amban would deal hardly with him. Very few people knew anything about this incident. As to Dorjieff he was now in his own country. He was one of seven assistants to his chief spiritual adviser and had never had anything to say to any but spiritual matters. ${ }^{1}$

Minto "approved" the preceding minute on the file and S. H. Butler, then Secretary, Foreign Department, ${ }^{2}$ added that the above was "what passed at the private interview" which the Governor-General had granted the Lama on the afternoon of March 1o. Charles (later Sir Charles) Bell, then Political Officer in Sikkim, had been present and made "a few corrections and additions" to the note recorded above.

Earlier Bell had himself met the Dalai Lama at Darjeeling-shortly after his arrival in India-and in a telegram to the Foreign Secretary on March 3 (1910) informed his superiors,

At noon today I called on the Dalai Lama. He rose from his seat to receive me.... On the Dalai Lama commencing to discuss the reason of his coming to India, everybody including Maharajkumar of Sikkim quitted the room leaving Dalai Lama and myself alone. He proceeded to say that when U-gyen Kazi presented letter before the recent Tibet mission, he, the Dalai Lama would not accept it on account of his agreement with China to act solely through Chinese intermediaries in foreign affairs. Similarly the Chinese refused to permit him to reply when Colonel Younghusband wrote to him during the Tibet mission. ${ }^{3}$

A little over a year later while recommending the Kazi for the title of "Raja," Bell referred again to Lord Curzon's letter in the opening years of the century.

In 19or, at great personal risk, while on a private journey to Lhasa, he (U-gyen Kazi) presented His Excellency the Viceroy's letter to the Dalai Lama. The latter refused to accept

1 Foreign Department Proceedings, Secret External, Nos. 276-550, June I910, office-note, pp. 24-25.

References to the interview are also to be found in Minto to Morley, letter, March 17, 1901 and Morley to Minto of the same date, Minto Papers. Complimenting the Viceroy on his handling of the Lama "with entire correctness," Morley warned: "But we must not take his story for gospel, still less must we allow him to set England and China at loggerheads for the sake of his beaux yeux."

2 Spencer Harcourt Butler had been Deputy Commissioner at Lucknow from where Lord Minto picked him up in 1907 to be Secretary in the Foreign Department. Later he was to be the first Education Member of the Viceroy's Executive Council.

3 Proceeding No. 305 , in I Supra, Telegram P, No. 7/S, dated (and received) March 3, 1910. 
the letter. The Government of India are aware that in connection with this episode the Rai Bahadur remained for a long time under a cloud of suspicion having been raised by his enemies that he had not delivered the letter as stated. He was finally cleared by the Dalai Lama himself referring twice in conversation to the presentation of this letter. The first conversation was with me, the second with Lord Minto at Government House, Calcutta, in March, 1910. ${ }^{4}$

The above should serve to set at rest the

\footnotetext{
4 Proceeding No. 334 in Foreign Department, In-
} ternal B, February 1912, Nos. 334-37. long-standing controversy regarding the role of the Kazi in carrying Lord Curzon's letter to the Dalai Lama. One could not perhaps do better than end up with the last sentence with which an earlier article on the subject drew to a close: "Is it not time to re-assess the evidence and revise the harsh, and hasty, judgment of His Excellency which has come down to us, namely that Kazi U-gyen was 'a liar' and a 'paid Tibetan spy?" "'5

P. L. Merra

\section{The Panjab University}

${ }^{5}$ P. L. Mehra, "Kazi U-gyen: 'A Paid Tibetan Spy?" ", IRCAS, LI, 3-4, July-October 1964, 301-5.

\section{ERRATA NOTICE}

A Soviet History of Pakistan. By YURI V. GANKovskiY AND L. R. GoRdon-PolonSKAYA. First published as Istoriya Pakistana, Moscow: State Publishing House for Eastern Literature, 196r; translated by Joint Publications Research Service, Department of Commerce, Washington, as JPRS 36, 250, June 1966. $400 \mathrm{pp}$. Bibliography. $\$ 7.25$.

The publisher of the above wishes to correct the impression of the reviewer (JAS, Vol. XXVI, No. 2: February 1967, pp. 31214) that this is a "machine-translated edition." In fact, the translation was done by one of the many contract translators of the Joint Publications Research Service.

The publishers have also notified us of a new pricing system whereby single copies of any JPRS report, including this one, are now available at a unit price of $\$ 3.00$ per copy. 